\title{
MODERN TENDENCIES IN TEACHING THE ENGLISH LANGUAGE FOR FUTURE MANAGERS
}

СУЧАСНІ ТЕНДЕНЦІї В НАВЧАННІ АНГЛІЙСЬКОї МОВИ МАЙБУТНІХ МЕНЕДЖЕРІВ

\begin{abstract}
In the paper it is emphasized that modern pedagogical technologies are the tool to form a wide range of competencies in the field of teaching a foreign language. The basic principles of the research are historical, systematic and comparative methods, institutional and structural-functional approaches have been used. The subject of the study is the theoretical, methodological and practical questions in the field of teaching a foreign language. The importance of teaching a foreign language of future specialists is revealed. Foreign language learning and teaching have undergone a significant paradigm shift as a result of the research and experiences that have expanded the scientific and theoretical knowledge base on how students learn and acquire a foreign language. It has been shown, that language teaching has experienced numerous curricular innovations in response to the importance of providing students with opportunities to acquire and practice the foreign language in contextualized and meaningful language communicative tasks at all stages of the second or foreign language acquisition process. The authors point out that, the issue of methodological principles and models of using a foreign language as a language of instruction in obtaining higher professional education does not find sufficient coverage in the pedagogical literature. It has been defined that a detailed study of the European and international experience in organizing the training process through the use of English as an educational platform for attracting international teaching staff and expanding the educational space for higher education is required.As a result of the study, the main problems of teaching English have been pointed out.

Key words: teaching English, methodological principles, language communicative tasks, professional and moral quality, management,modern pedagogical technologies.
\end{abstract}

Candidate of Pedagogical Sciences, Associate professor,

Associate Professor of the Department of Business Communication

Zaporizhzhya National University Nadtochy N.A.,

Candidate of Pedagogical Sciences, Associate Professor,

Associate Professor of the Department of English Philology

Zaporizhzhya National University зазнало значної зміни парадигми внаслідок досліджень і досвіду, які розширили науковотеоретичну базу знань щодо того, як студенти навчаються та здобувають іноземну мову. Показано, що викладання мови зазнало численних нововведень у навчанні у відповідь на важливість надання учням можливостей опановувати та практикувати іноземну мову в контекстуалізованих і змістовних мовних комунікативних завданнях на всіх етапах процесу засвоєння другої чи іноземної мови. Автори описують деякі принципи, спрямовані на розвиток інтелектуальнотворчого потенціалу фрахівця у процесі іншомовної освіти.

У статті підкреслюється, що сучасні педагогічні технології виступають інструментом формування широкого спектру компетенцій у ссрері міжкультурної комунікації. Реалізація цих принципів в освітньому процесі вишу сприяє ефрективному фрормуванню мотиваційної готовності до навчання і профресійної діяльності. Аналіз загальних і профресійних компетенцій показує, що державі потрібен фрахівець, здатний проаналізувати значні проблеми нашого суспільства, знайти організаційні рішення та готовий брати на себе відповідальність за них, дотримуватися етичних цінностей. Автори зазначають, що питання методичних принципів і моделей використання іноземної мови як мови навчання під час отримання вищої профресійної освіти недостатньо висвітлене в педагогічній літературі. Визначено, що потрібно детальне вивчення європейського та міжнародного досвіду організації навчального процесу за допомогою використання англійської мови як освітньої платфрорми для залучення міжнародних викладачів і розширення освітнього простору для вищої освіти. Таким чином, формування професійних та особистісних якостей, однією з яких $\epsilon$ професійна відповідальність, є важливою соціальною та державною вимогою до вищої освіти у процесі підготовки майбутнього керівника.

Ключові слова: викладання англійської мови, методологічні принципи, мовні комунікативні завдання, професійна та моральна якість, управління, сучасні педагогічні технології.
Formulation of the problem. Good knowledge of a professional foreign language for modern specialists is one of the conditions for successful work. New educational paradigms related to vocational training and competencies are being created [1-3]. Already a considerable time in the framework of the competence approach, one of the leading ones in the field of education, intensive studies of theoretical models of foreign language communicative and professional competencies are being conducted [4, p. 234; 5], revealing the psychological and pedagogical mechanisms of development [6-8], in which communicative and professional competencies are defined as one of the aspects of human competence, ensuring the receipt and processing of information [9, p. 63], the ability to create meanings, determining the potential property of each language for constant modification in response to changes. Intensive social-economic development in Ukraine caused some changes in modern society. Nowadays, the change in priorities which aim is to obtain material benefits and high social status, the depreciation of moral values, which indicates the moral crisis in modern society, is most clearly seen. Thus, the problem of preparing a future 
specialist in a higher educational institution is one of the most important in the system of higher education. Higher education is faced with the task of preparing a specialist with professional and moral qualities that meet the requirements of society.

The analysis of general and professional competencies shows that the state needs a specialist who is able to analyze significant problems of our society, find organizational solutions and is ready to take responsibility for them, to adhere to ethical values. Thus, the formation of professional and personal qualities, one of which is professional responsibility, is an important social and state requirement for higher education in the process of preparing a future manager.

Analysis of recent research and publications. Language education, its current state and prospects for Ukraine, language policy in the field of education are constantly being discussed in the pedagogical community. The central components that are changed during the last years are being discussed as well. They are, first and foremost, the personality and professionalism of the teacher, the linguistic examination education as additional education. On the other hand, there are innovative technologies, that came to the educational process, new authentic guides, new social issues, student's practice.

Problems of English language training of university students were analyzed in the scientific literature (I.A. Solomakh, G.S. Popova, G.A. Sumina, N.Yu. Ushakova, T.I. Koshelev, N.Yu. Khlyzova, O. Talbberg, R.M. Felder, B. Stappenbelt, S. Barrett-Lennard, K. Haycock, F. Malhouser, M. Chase, M. Raymer). All these researchers also confirm the fact that the English-language training of students technical profile does not always meet modern requirements.

Formulation of article objectives. The problem of formation of English competence of students of management has some contradictions: the first contradiction lies between the theoretical and the a practical approach to the problem from everyone who is affected by this problem; the second is between the understanding by a modern specialist necessity of knowledge of English and his actual level of knowledge of the language; the third one is between understanding the need to use multimedia and English teaching technologies with the use of Internet resources and the absence of anychanges in the planning of the educational process, the formulation of new tasks, clarification the goals of each level of education, and in developing a systematic approach to using multimedia learning tools, creating new, more modern and effective technologies and teaching methods. V.A. Abchuk, M.T. Gromkova, O.L. Gelikh, Yu.N. Dulin, D.V. Chernilevsky and others also point to the update of the content of education and the concepts of training managers. Thus, we can talk about a paradigm shift education, which, in turn, changes the leading goals and content of the educational process, the rejection of established stereotypes, conservative systems, the transition to more dynamic, flexible structures that quickly respond to changes in the surrounding global space.

As for the managerial profession, there are some difficulties associated with the fact that the science of management is relatively young and the management professionalism is at a stage of development and formation. This fact has a significant impact on the training of specialists: a definition of the psychological type of trainees is needed, and that fact influences the selection of the content of the subject and the organization of the educational process.

The new content of the subject requires that teachers manage knowledge (grammatical rules and language information), skills (listening, speaking, reading, writing), attitude (moral values), literary evaluation and communicative learning activities. This is indeed a difficult approach compared to traditional types of work. David R. Carless offers goal-oriented content, presenting it as an integral system for improving the quality of teaching, learning and assessment. The goal-oriented content provides the structure through which students go towards a specific goal, actively fulfilling learning tasks taking into account the common European competences of foreign language proficiency.

The purpose of this article is to present methodological materials that provide an aspect of teaching a foreign language, which is commonly called "learning the language of a specialty or the language of professional communication. Aspects or integrated parts is a direction of student work, usually determined by the students themselves, corresponding to different levels of learning and communication tasks [4, p. 105].

Outline of the main results. Thematic area of the aspects is a variety of business areas and areas of intercultural communication. The aspect has purpose to help students develop intercultural communicative competence to realize professionally significant competencies. English is an important component that ensures the effectiveness of the implementation of the portfolio. Each aspect is made in the form of training sections. For each section, a topic is selected and a lesson is planned that integrates the practice of developing listening, speaking, reading and writing skills, as well as grammatical and lexical aspects in the context of the topic. All these aspects focuses on the personal activities of students. In addition, the teacher must be sure that declarative-vitagenic, cognitive-research, literary-analytical and existential elements are integrally embedded in each training section through suitable (adequate) activity and material. Since the key concept of the research is the centering of studies on the professional interests of the trainees and the local government, an educational-methodical complex was selected. It should contain a case-study 
(authentic cases from management practice). This thematic area is an interesting and productive basis, corresponding to the knowledge and understanding of future managers, as well as a fairly high level of English proficiency. Thus, learning is relatively easy to focus on the use of a foreign language for professional purposes. In addition, students of this level already possess communication skills, experience and are ready for such work.

Students should take great responsibility for their activities, as well as have the freedom and authority to make decisions about their studies, learn to set goals and evaluate their progress, set their own criteria. Moreover, it is possible to encourage students to work together and provide feedback both with each other and with the teacher. It is especially important that they feel responsible for their learning, use their ability to communicate in English, and strive to improve their communication skills. Thus, learning should be flexible, and students should become active actors in the educational process, not passive recipients of ready information. In this context, the level of formation of the necessary skills and abilities is a product of the students' own actions, which is based on their vitagen experience and interests. At the same time, the teacher - coach performs many other functions: helps students develop awareness of learning goals, choice of material, analyzes the needs of students, delegating responsibility for making decisions and engaging in an interactive educational process.

The main aspect includes the "Market Leader" educational methodical complex pre - intermediate level (corresponding to B1). This complex was designed for students of 1-2 courses (I-III semesters) [6]. The name of the complex itself can motivate students to achieve a higher level of professional and communicative competence. The next aspect consists of the intermediate "Market Leader" educational methodical complex (B1-B2). This course wasdeveloped for students of 2-3 courses (IV-VI semesters) [7]. In addition, a special course "Basics of Cross/Intercultural Management" is introduced in the III-IV semesters.

Some additional questions and practical tasks are from the educational study book by S.P. Myasoyedov "Basics of cross-cultural management: how to do business with representatives of other countries and cultures" [5], as well as the study guide LMEnglish, S. Lynn "Business across Cultures. Effective Communication Strategies [9]. This course contributes to a deeper and more complete understanding of the sections of textbooks "Market Leader", as it helps to connect theory and practice and, thus, to implement the theory "in action", consciously solving problems both in the intra- and in the intercultural environment.
This supplimentation is consistent with the approach of "action learning in cooperation" (cooperative action learning) and contributes to the further development of intercultural communicative competence. During the $\mathrm{V}-\mathrm{VI}$ semesters, in addition to the educational guide "Market Leader", a course "Public Relations" is introduced. The intermediate level is supplemented by the formation of special speech skills. The purpose of this course is to familiarize students with the types of communication and techniques of writing and compiling speeches, presentations, promotions, their lexical and grammatical features, and forming the ability to influence other people. The choice of this direction is due to the growing need to succeed in a competitive environment where you need to be heard. It is the communication theory that makes it possible to establish connections between various sectors of society, between a firm and a client, between producers and consumers.

In order to develop and improve the skills of translation, especially from Ukrainian into English, students are offered various additional material selected by the teacher. In particular, the material from the textbook V.V. Kabakchi "The Practice of English Intercultural Communication" is used. The purpose of the book is to teach the use of English in communication with representatives of foreign cultures. The book is intended for professionals who need fluency in English as a means of intercultural communication. Starting from the III semester, students are offered an independent reading of special literature related to the topic of business, followed by a discussion of the features of doing business in organizations of various types, interpersonal relationships, training and the development of young managers and managers, etc. Together with this, students become familiar with the literature of the countries which language they study. Assessment of knowledge and skills of students is carried out with the help of testing materials attached to educational and methodological complexes, as well as during tests and exams, in accordance with the curriculum. Students can prepare different presentations on the topic they chose, take part in conferences of various levels held in foreign languages with the subsequent publication of articles and reports in collections of conference materials.

Outline of the main results. Thus, having obtained empirical data on the contingent of students and identifying the main pedagogical tasks and methods for their implementation, we were able to fill the aspect of teaching English with professional-oriented content that most closely matches the psychological type of student managers and develops intercultural communicative competence in order to implement professional communication. 


\section{REFERENCES:}

1. Антонюк Н.М., Титаренко О.Ю., Горохова I.В. Вивчення іноземних мов в контексті гуманістичної освіти. Вісник Академії адвокатури України. 2009. № 1. С. 228-233.

2. Безкоровайна О.В., Мороз Л.В. Актуальні аспекти комунікативної компетенції студентів ВНЗ. Наукові записки Національного університету «Острозька академія»]. Серія : Філологічна. 2012. № 25. C. 142-145.

3. Бігич О.А., Санжаревська В.О. Види індивідуалізації навчання аудіювання та шляхи їх реалізації. Гуманістичні аспекти лінгвістичних досліджень $і$ методики викладання іноземних мов : збірник наукових праць. Київ : КДПІІМ, 1992. С.152-158.

4. Горчакова-Сибирская М.П. Социальное пространствокакусловиеменеджментакачествапрофессионального образования. Менеджмент XXI века: проблемы качества : Материалы IV междунар. науч.-практ. конф. Санкт-Петербург : Книж. дом, 2004. C. 111-112.

5. Захарова Е.В., Ульянищева Л.В. Public relations and Advertising in Close-up. Москва : ИМПЭПАБЛИШ, 2004. 272 c.

6. Ігнатюк О.А. Особливості підготовки сучасних фрахівців у системі вищої професійної освіти США. Теорія і практика управління соціальними системами. 2011. № 1. С. 55-64.

7. Іщенко О., Матвіяс О. Вивчення англійської мови в умовах вступу України у європейський освіт- ній простір. Вісник Львівського університету. 2009. № 25. C. 353-357.

8. Кабакчи В.В. Практика английской межкультурной коммуникации. Санкт-Петербург : Союз, 2004. $480 \mathrm{C}$

9. Мясоедов С.П. Основы кросскультурного менеджмента: как вести бизнес с представителями других стран и культур. Москва : Дело, 2003. 256 с.

10. Ніколаєва Ж.В. Навчання іноземних мов у ВН3 у контексті Загальноєвропейських Рекомендацій з мовної освіти. Наукові праці. Педагогічні науки. 2004. № 29. C. $127-130$

11. Полікарпова Ю.О. Традиції та інновації у викладанні іноземних мов в умовах інтеграції України до світової спільноти. 2004. URL: http://www. academia.edu/2079153/.

12. Рудницька Т.Г. Інноваційні методи навчання іноземних мов у вищій школі в контексті гуманістичної спрямованості навчального процесу. Гуманізм та освіma. 2008. URL: http://conf.vntu.edu.ua/ humed/2008/txt/Rudnizka.php.

13. Cotton D., Falvey D., Kent S. Market Leader: Pre-Intermediate Business English. England : Pearson Education Limited, 2003, 176 p.

14. Cotton D., Falvey D., Kent S. Market Leader: Intermediate Business English. England : Pearson Education Limited, 2003. 176 p.

15. Dubicka I., O'Keeffe. Market Leader: Advanced Business English. England : Pearson Education Limited, 2006. $176 \mathrm{p}$. 